\title{
Quantum-chemical, NMR, FT IR, and ESI MS studies of complexes of colchicine with $\mathrm{Zn}$ (II)
}

\author{
Wojciech Jankowski $^{1}$ (D ) Joanna Kurek ${ }^{1} \cdot$ Piotr Barczyński $^{1} \cdot$ Marcin Hoffmann $^{1}$
}

Received: 26 October 2016 / Accepted: 6 March 2017 / Published online: 20 March 2017

(C) The Author(s) 2017. This article is published with open access at Springerlink.com

\begin{abstract}
Colchicine is a tropolone alkaloid from Colchicinum autumnale. It shows antifibrotic, antimitotic, and anti-inflammatory activities, and is used to treat gout and Mediterranean fever. In this work, complexes of colchicine with zinc(II) nitrate were synthesized and investigated using DFT, ${ }^{1} \mathrm{H}$ and ${ }^{13} \mathrm{C}$ NMR, FT IR, and ESI MS. The counterpoise-corrected and uncorrected interaction energies of these complexes were calculated. We also calculated their ${ }^{1} \mathrm{H},{ }^{13} \mathrm{C} \mathrm{NMR}$, and IR spectra and compared them with the corresponding experimentally obtained data. According to the ESI MS mass spectra, colchicine forms stable complexes with zinc(II) nitrate that have various stoichiometries: $2: 1,1: 1: 1$, and 2:1:1 with respect to colchichine, $\mathrm{Zn}(\mathrm{II})$, and nitrate ion. All of the complexes were investigated using the quantum theory of atoms in molecules (QTAIM). The calculated and the measured spectra showed differences before and after the complexation process. Calculated electron densities and bond critical points indicated the presence of bonds between the ligands and the central cation in the investigated complexes that satisfied the quantum theory of atoms in molecules.
\end{abstract}

This paper belongs to Topical Collection 7th Conference on Modeling \& Design of Molecular Materials in Trzebnica (MDMM 2016)

Electronic supplementary material The online version of this article (doi:10.1007/s00894-017-3306-z) contains supplementary material, which is available to authorized users.

Wojciech Jankowski

wojciech.jankowski89@gmail.com

1 Faculty of Chemistry, Adam Mickiewicz University in Poznan, ul. Umultowska 89b, 61-614 Poznań, Poland
Keywords Colchicine Complexes of colchicine with metal cations · Quantum chemical calculations · DFT · ESI MS · NMR · FT IR
Abbreviations
DFT
Density functional theory
FT IR Fourier transform infrared spectroscopy
NMR Nuclear magnetic resonance
ESI MS Electrospray ionization mass spectrometry
TRAAK Potassium channel subfamily K member 4

\section{Introduction}

Colchicine (Fig. 1) is a tropolone alkaloid from Colchicum autumnale. It naturally occurs as a neutral molecule; it does not form salts because of its very low basicity. This alkaloid possesses antimitotic, antifibrotic, anti-inflammatory activities. For instance, it can efficiently alleviate the symptoms of gout when applied in the early phase because of its antiinflammatory properties [1-3], and it is a potent antimitotic agent, showing anticarcinogenic activity $[4,5]$. As also seen for other alkaloids, colchicine can block or activate specific receptors (for example P2X7 and P2X2 [6]) or ion channels (for example the TRAAK [7] potassium channel) in living organisms. Its activity depends on its ability to form noncovalent complexes with macromolecules such as tubulin in microtubules.

There are only a few studies of the formation of complexes between colchicines and cations [8]. In 1998, Mackay et al. obtained hydrated crystals of copper(II) colchiceine (10demethoxy-10-hydroxycolchicine) [9]. In a previous work, we reported the coordination of colchicine to iodides and perchlorates with monovalent metal ions (lithium, sodium, and 
Fig. 1 Numbering scheme used for carbon and oxygen atoms in colchicine 1

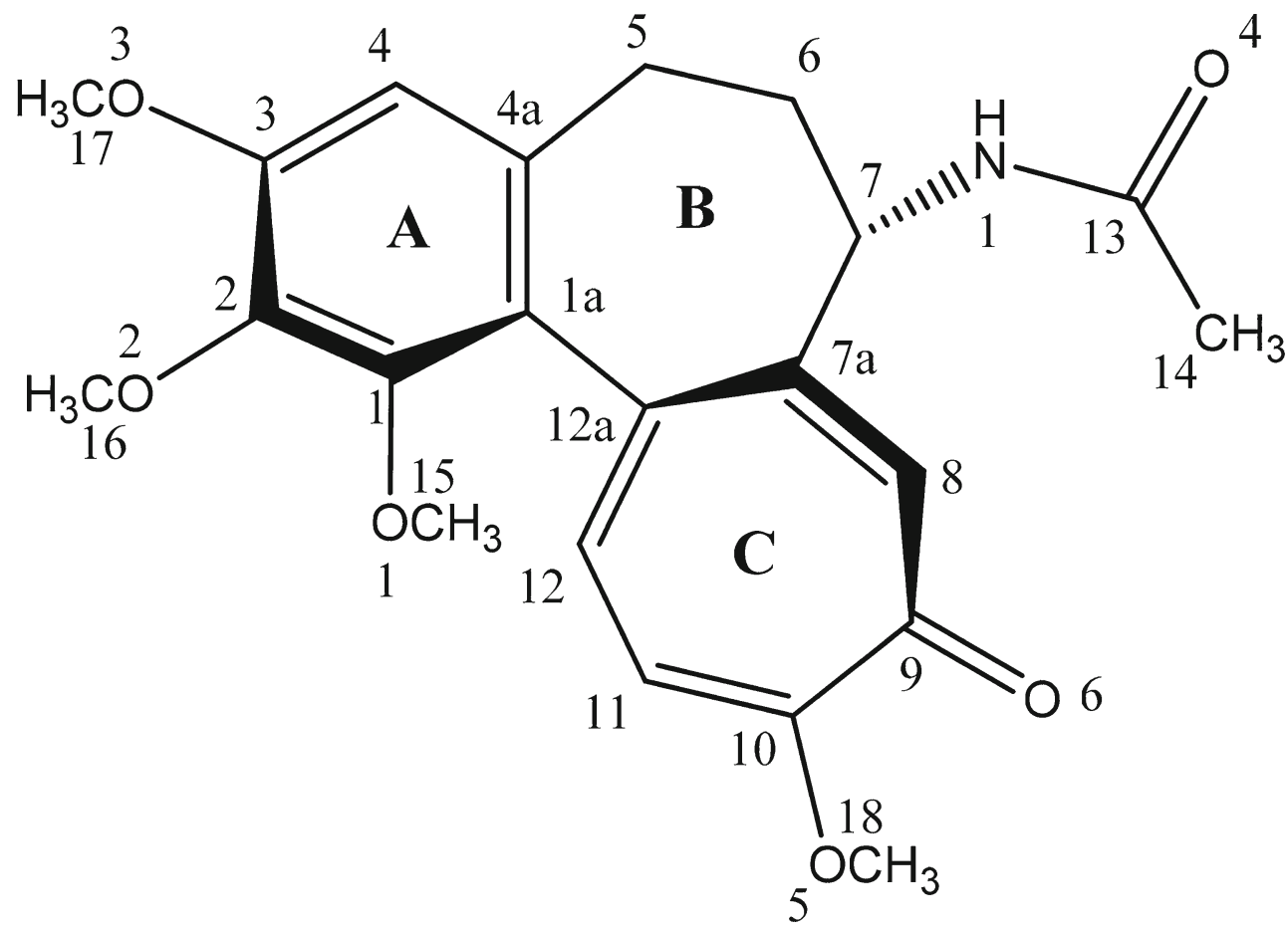

potassium salts) [10]. Recent ab initio studies of the $\mathrm{Na}^{+}-$ colchicine complex showed that its most stable geometry is obtained when the $\mathrm{Na}^{+}$ion is located above the methoxytropolonic ring (Fig. 1, ring C) [11].

Complexes with zinc are interesting because zinc cations are biologically important for plants and animals. Zinc is responsible for a number of different functions in the human body because it is associated with various biomolecules (for example carbonic anhydrase, thermolysin, 5-aminolevulinate dehydratase) $[12,13]$. It is the second most abundant metal (after iron) in the human body; it is essential for growth and development and plays important roles in various biological systems [14]. Zinc fingers play a crucial role in DNA base sequence recognition during the replication and transcription of DNA. Approximately $10 \%$ of all proteins in the human body can bind zinc, and hundreds of them can transport it $[15,16]$. Zinc also plays a role in the brain. It has a specific neuromodulatory role in addition to its other cellular functions $[17,18]$.

From a practical point of view, the process of complexation can be useful for isolating colchicine from plant extracts or for effectively separating (complexed) colchicine from mixtures in HPLC methods. Indeed, colchicine can form stable complexes with zinc cations in human body fluids following the administration of colchicine as a drug during antigout therapy (i.e., patients take pills in which the active substance is colchicine).

Although colchicine is a very important commercially available alkaloid, its complexes (except for those with lithium, sodium, and potassium [10]) and the complexes of colchicine derivatives have generally not been thoroughly characterized. For instance, the process for the complexation of colchicine with zinc nitrate has not yet been studied. This fact prompted us to synthesize and examine complexes of colchicine with zinc(II) nitrate experimentally and computationally to find out if colchicine is likely to interact with the $\mathrm{Zn}$ (II) cation in the human body.

\section{Experimental methods}

\section{Materials}

Colchicine 1 was obtained from AppliChem (Darmstadt, Germany). The natural isomer of colchicine (-)-(aR,7S)-colchicine was used for complexation. The salt $\mathrm{Zn}\left(\mathrm{NO}_{3}\right)_{2}$ was obtained from Sigma-Aldrich (St. Louis, MO, USA) and used without any further purification. Solvents used for the synthesis were obtained from Sigma-Aldrich and purified by standard methods.

\section{Synthesis of the 1:1 complex of colchicine with zinc(II) nitrate}

The 1:1 complex of zinc(II) nitrate with colchicine $\left[\mathrm{Zn}\left(\mathrm{C}_{22} \mathrm{H}_{25} \mathrm{NO}_{6}\right)\left(\mathrm{NO}_{3}\right)_{2}\right]$ was obtained by dissolving the respective salt $(76 \mathrm{mg}, 0.25 \mathrm{mM})$ and colchicine $(100 \mathrm{mg}$, $0.25 \mathrm{mM}$ ) in the ratio $1: 1 \mathrm{in} 10 \mathrm{~mL}$ of methanol. This mixture was stirred for $24 \mathrm{~h}$ at room temperature. The solution was evaporated until the product began to precipitate. The 
resulting precipitate was filtered off and recrystallized from methanol, and this colchicine complex was studied by spectral analysis using ESI MS, ${ }^{1} \mathrm{H}$ and ${ }^{13} \mathrm{C}$ NMR, and FT IR as well as theoretically. The carbon atom numbering scheme used for colchicine $\mathbf{1}$ is shown in Fig. 1.

\section{Measurements}

ESI (electrospray ionization) mass spectra were recorded on a Waters/Micromass (Manchester, UK) ZQ mass spectrometer equipped with a Harvard Apparatus (Holliston, MA, USA) syringe pump. All samples were prepared in acetonitrile. The measurements were performed on solutions of colchicine $\left(5 \times 10^{-5} \mathrm{~mol} \mathrm{dm}^{-3}\right)$ with $\mathrm{Zn}$ (II) nitrate $\left(2.5 \times 10^{-4} \mathrm{~mol}\right.$ $\mathrm{dm}^{-3}$ ). The sample was infused into the ESI source using a Harvard Apparatus pump at a flow rate of $201 \mathrm{~min}^{-1}$. The ESI source potentials were: capillary $3 \mathrm{kV}$, lens $0.5 \mathrm{kV}$, extractor $4 \mathrm{~V}$. Standard ESI mass spectra were recorded at $30 \mathrm{~V}$. The source temperature was $120^{\circ} \mathrm{C}$ and the desolvation temperature was $300{ }^{\circ} \mathrm{C}$. Nitrogen was used as the nebulizing and desolvation gas at flow rates of 100 and $300 \mathrm{dm}^{3} \mathrm{~h}^{-1}$, respectively. Mass spectra were acquired in the positive ion detection mode with unit mass resolution in steps of $1 \mathrm{~m} / \mathrm{z}$ unit. The mass range applied in the ESI experiments was from $\mathrm{m} / \mathrm{z}=100$ to $\mathrm{m} /$ $z=1400$. Elemental analysis $(\% \mathrm{C}, \mathrm{N}, \mathrm{H})$ was carried out by means of a Vario EL III element analyzer (Elementar Analysensysteme GmbH, Langenselbold, Germany). Melting point data were obtained with a BÜCHI Labortechnik AG (Flawil, Switzerland) SMP-20 and a Mel-Temp II apparatus (Laboratory Devices Inc., Holliston, MA, USA).

NMR spectra of colchicine and its complex with zinc(II) nitrate $\left(0.07 \mathrm{~mol} \mathrm{~L}^{-1}\right)$ were recorded in $\mathrm{CD}_{3} \mathrm{CN}$ solution using a Varian (Palo Alto, CA, USA) Gemini 300 MHz spectrometer. All spectra were locked to the deuterium resonance of $\mathrm{CD}_{3} \mathrm{CN}$. ${ }^{1} \mathrm{H}$ NMR measurements in $\mathrm{CD}_{3} \mathrm{CN}$ were carried out at an operating frequency of $300.075 \mathrm{MHz}$; flip angle, pw $=45^{\circ}$; spectral width, $\mathrm{sw}=4500 \mathrm{~Hz}$; acquisition time, at $=$ $2.0 \mathrm{~s}$; relaxation delay, $d_{1}=1.0 \mathrm{~s} ; T=293.0 \mathrm{~K}$, and using TMS as the internal standard. No window function or zero filling was used. The digital resolution was $0.2 \mathrm{~Hz}$ per point. The error in the chemical shift value was $0.01 \mathrm{ppm} .{ }^{13} \mathrm{C}$ NMR spectra were recorded at an operating frequency of $75.454 \mathrm{MHz} ; \mathrm{pw}=60^{\circ} ; \mathrm{sw}=19000 \mathrm{~Hz}$; at $=1.8 \mathrm{~s} ; d_{1}=$ $1.0 \mathrm{~s} ; T=293.0 \mathrm{~K}$, and using TMS as the internal standard. Line-broadening parameters were 0.5 or $1 \mathrm{~Hz}$. The error in the chemical shift value was $0.01 \mathrm{ppm}$. The ${ }^{1} \mathrm{H}$ and ${ }^{13} \mathrm{C} \mathrm{NMR}$ signals were assigned for each species using one- or twodimensional (COSY, HETCOR, HMBC) spectra. FT IR spectra of colchicine and its complex with zinc nitrate $(0.07 \mathrm{~mol}$ $\mathrm{dm}^{-3}$ ) were recorded in the mid-infrared region in $\mathrm{KBr}$ pellets, nujol, and $\mathrm{CD}_{3} \mathrm{CN}$ using a Bruker (Karlsruhe, Germany) IFS $113 \mathrm{v}$ spectrometer equipped with a DTGS detector; resolution $2 \mathrm{~cm}^{-1}, \mathrm{NSS}=125$. A cell with $\mathrm{Si}$ windows and wedge- shaped layers was used to avoid interference (mean layer thickness: $170 \mu \mathrm{m})$. Each FT IR spectrum was measured by acquiring 64 scans. All manipulation of the substances was performed in a carefully dried and $\mathrm{CO}_{2}$-free glove box.

\section{Theoretical calculations}

All of the structures needed for the theoretical calculations were obtained from the known crystal structure of colchicine dehydrate (COLCDH) [19]. Energy calculations were performed using DFT at the M06/SDD level of theory [20, 21], which was selected on the basis of the results from the extensive comparative studies of Zhao and Truhlar [20] and because it is recommended for calculations of compounds containing metal atoms [13, 20-22]. Partial atomic charges were calculated at the same level of theory. In our studies, we utilized Mulliken [23] point charges. We also calculated the Wiberg bond indices [24] by natural bond orbital (NBO) analysis $[25,26]$ for the bonds between the ligands and the central zinc(II) cation in all of the investigated complexes. The counterpoise correction $[27,28]$ was calculated to assess the basis set superposition error (BSSE). IR spectra were calculated at the same level of theory as that used to perform the geometry optimizations. NMR spectra were calculated using the M06 functional with the SDD and pcS-2 basis sets [29] (the latter is recommended for use when calculating NMR shifts for complexes with organic molecules [30]) using the usual GIAO (gauge-independent atomic orbital) method [31]. Energy, NMR, and IR calculations were performed in the presence of solvent using the PCM model [32]. The M06/6-31+ $\mathrm{G}(\mathrm{d}, \mathrm{p})[33]$ level of theory was used to calculate bond critical points. That allowed us to determine whether colchicine forms bonds with the zinc(II) cation that satisfy the QTAIM (quantum theory of atoms in molecules) [34]. All quantummechanical calculations were performed in Gaussian 09 [35].

The conformation of the seven-membered ring in colchicine (ring B; see Fig. 1) was examined as described by Cremer and Pople [36], Boessenkool and Boyens [37], and Bocian et al. [38]. Four conformational parameters of the sevenmembered ring were calculated: two puckering amplitudes $q_{2}$ and $q_{3}$ and two phase angles $\varphi_{2}$ and $\varphi_{3}$. Those parameters were calculated according to the following equations:

$$
\begin{aligned}
& \rho_{m} \cos \varphi_{m}=\left(\frac{2}{N}\right)^{0.5} \sum_{j=1}^{N} z_{j} \cos \left[\frac{2 \pi m(j-1)}{N}\right] \\
& \rho_{m} \sin \varphi_{m}=\left(\frac{2}{N}\right)^{0.5} \sum_{j=1}^{N} z_{j} \sin \left[\frac{2 \pi m(j-1)}{N}\right],
\end{aligned}
$$

where:

$$
\begin{array}{ll}
m & \text { is } 2 \text { or } 3 \\
\rho_{m} & \text { is a puckering amplitude }
\end{array}
$$


$\varphi_{m} \quad$ is a phase angle

$N \quad$ is the number of atoms in the ring

$z_{j} \quad$ is the displacement from the main plane, calculated from the position vector of atom $j$.

As defined by Boessenkool and Boyens [37], each ring conformation was categorized as either a chair, twisted chair, boat, twisted boat, sofa, or twisted sofa. All conformational parameters of the seven-membered ring were calculated starting from carbon atom $\mathrm{C} 7$ (see Fig. 1) and moving clockwise, i.e., in the order C7-C7a-C12a-C1a-C4a-C5-C6 (see Fig. 2). The $\mathrm{C} 7$ atom was chosen as the starting point because it was the atom that was furthest out of plane in the majority of the most energetically favored structures.

\section{Results and discussion}

\section{ESI MS measurements}

Only three signals (at $m / z=431,525$, and 924) were observed in the ESI mass spectra obtained after complexation, which were assigned to colchicine- $\mathrm{Zn}$ (II) and colchicine- $\mathrm{Zn}$ (II)$\mathrm{NO}_{3}$ complexes. The $\mathrm{m} / \mathrm{z}$ signals in the ESI mass spectra of the complex formed between colchicine and zinc(II) nitrate at a cone voltage of $30 \mathrm{~V}$ are given in Table 1 and are shown in Fig. 3. The signal at $m / z=431$ was assigned to a complex with a stoichiometry of 2:1 (i.e., two colchicine molecules and one divalent metal cation). The signal at $m / z=525$ was assigned to a $1: 1: 1$ complex $\left[\text { colchicine }+\mathrm{Zn}^{2+}+\mathrm{NO}_{3}{ }^{-}\right]^{+}$. The third characteristic signal, at $m / z=924$, was assigned to a 2:1:1 complex $\left[2 \times \text { colchicine }+\mathrm{Zn}^{2+}+\mathrm{NO}_{3}{ }^{-}\right]^{+}$. For the full ESI mass spectral data, see Fig. S1 in the "Electronic supplementary material" (ESM).

\section{Theoretical studies}

The ESI MS studies showed that colchicine can form stable complexes with different stoichiometries $(2: 1,1: 1: 1$, and 2:1:1)

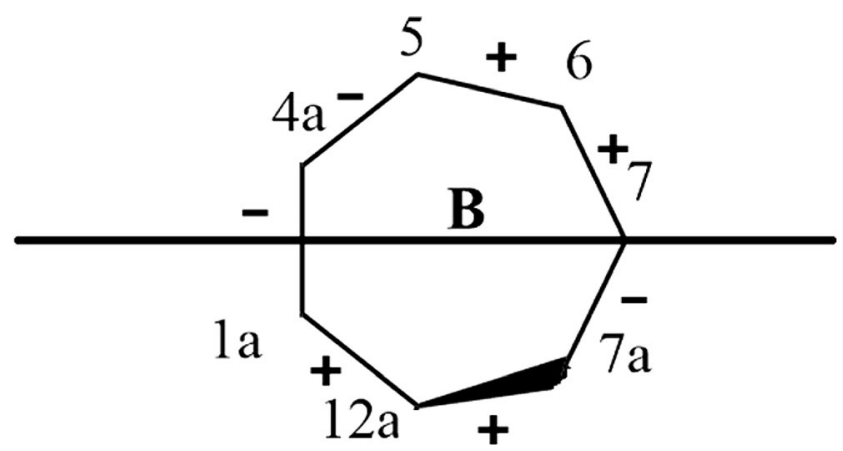

Fig. 2 Atom order used for conformational analysis; the signs of the dihedral angles for the most energetically favored structures are also shown
Table 1 Main peaks in the ESI mass spectra (obtained in $\mathrm{ES}^{+}$mode) of the complexes of colchicine with zinc(II) nitrate, measured at $\mathrm{cv}=30 \mathrm{~V}$

\begin{tabular}{llll}
\hline Complex & $m / z$ & & \\
\cline { 2 - 4 } & $2: 1$ & $1: 1: 1$ & $2: 1: 1$ \\
& {$\left[2 \times \mathbf{1}+\mathrm{Zn}^{2+}\right]$} & {$\left[\mathbf{1}+\mathrm{Zn}^{2+}+\mathrm{NO}_{3}{ }^{-}\right]$} & {$\left[2 \times \mathbf{1}+\mathrm{Zn}^{2+}+\mathrm{NO}_{3}{ }^{-}\right]$} \\
\hline Colchicine- $\mathrm{Zn}$ & 431 & 525 & 924 \\
\hline
\end{tabular}

$\mathbf{1}$ is the colchicine molecule

which may or may not contain a nitrate anion. Nine different interaction schemes of colchicine complexes with zinc nitrate based on previously described possible interactions [39] were subjected to further computational investigation.

The initial interaction schemes of the 1:1:1 complex (structures $\mathbf{A}-\mathbf{C}$ ) consisted of one molecule of colchicine, one zinc cation, and nitrate anion. In structure $\mathbf{A}$, colchicine coordinates with the zinc cation via three oxygen atoms $(\mathrm{O} 1, \mathrm{O} 2$, and O4). Structure $\mathbf{B}$ has the colchicine molecule coordinating to the zinc cation via $\mathrm{O} 5$ and O6. The colchicine molecule in structure $\mathbf{C}$ coordinates via the oxygen atoms $\mathrm{O} 1$ and $\mathrm{O} 3$. All of these structures have a charge of +1 . The optimized 1:1:1 structures are shown in Fig. 4.

Initial interaction schemes of the 2:1 complex of colchicine with $\mathrm{Zn}(\mathrm{II})$ (structures D-F) consisted of two molecules of colchicine and one zinc(II) cation. In structure $\mathbf{D}$, both molecules of colchicine are coordinated via $\mathrm{O} 1$ and $\mathrm{O} 4$, in structure E both colchicine molecules are coordinated via O5 and O6, while structure $\mathbf{F}$ has both colchicine molecules coordinated via $\mathrm{O} 4$ and N1. All of these structures have a charge of +2 . The optimized 2:1 structures are shown in Fig. 5.
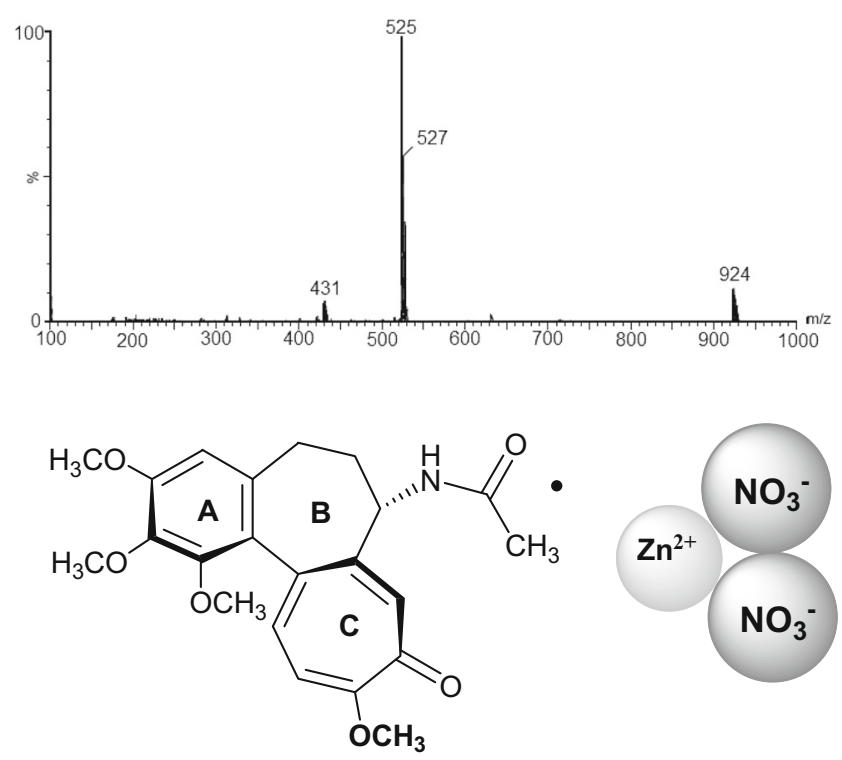

Fig. 3 The ESI mass spectra (obtained in $\mathrm{ES}^{+}$mode) of the complexes of colchicine with zinc(II) nitrate (i.e., $\mathbf{1}-\mathrm{Zn}$ ), as measured at $\mathrm{cv}=30 \mathrm{~V}$, as well as a diagram of the structure of the colchicine complex with $\mathrm{Zn}\left(\mathrm{NO}_{3}\right)_{2}$ 


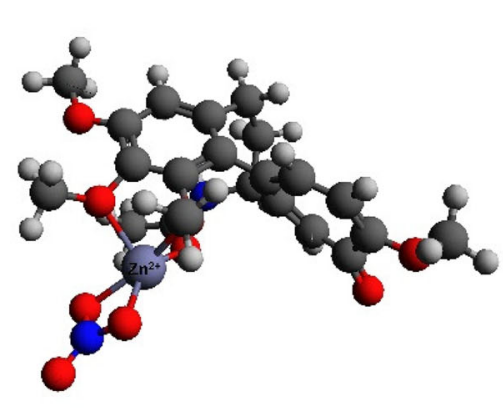

A

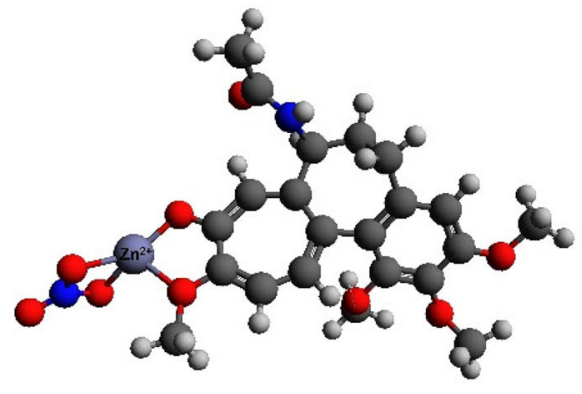

B

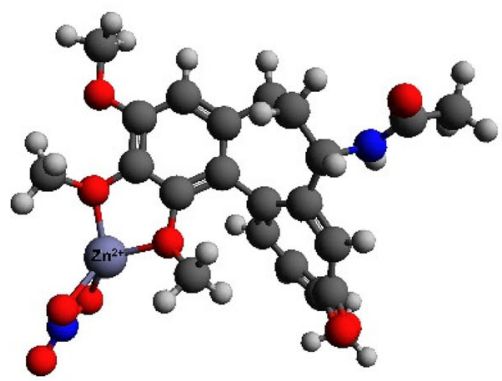

C

Fig. 4 Optimized structures A-C with 1:1:1 stoichiometry

The initial interaction schemes of the 2:1:1 complex (structures $\mathbf{G}-\mathbf{I}$ ) consisted of two colchicine molecules, one zinc(II) cation, and one nitrate anion, and all three of these structures have a charge of +1 . Structure $\mathbf{G}$ has both colchicine molecules coordinated to $\mathrm{Zn}(\mathrm{II})$ via $\mathrm{O} 1$ and $\mathrm{O} 4$, structure $\mathbf{H}$ has both molecules of colchicine coordinated to the zinc cation via $\mathrm{O} 5$ and O6, and in structure I, O4 and N1 of colchicine coordinate to the central $\mathrm{Zn}$ cation. The optimized 2:1:1 structures are shown in Fig. 6.

Table 2 shows the interaction energies for each of the structures $\mathbf{A}-\mathbf{I}$ in vacuum and in the presence of solvent (i.e., methanol, as used in the experimental studies). Table S1 in the ESM presents the extended version of Table 2, including values for the counterpoise energy, BSSE, and the sum of the energies of the monomers.

In vacuum, the structure with 1:1:1 stoichiometry that has the most favorable interaction energy $(-970.2 \mathrm{kcal} / \mathrm{mol})$ is $\mathbf{A}$; B was $12.4 \mathrm{kcal} / \mathrm{mol}$ less favorable and $\mathbf{C} 38.7 \mathrm{kcal} / \mathrm{mol}$ less favorable (see Fig. 3). In methanol, among the 1:1:1 structures, $\mathbf{A}$ was again the most favorable in terms of interaction energy $(-102.6 \mathrm{kcal} / \mathrm{mol}) ; \mathbf{B}$ and $\mathbf{C}$ were less favorable by $9.6 \mathrm{kcal} / \mathrm{mol}$ and $26 \mathrm{kcal} / \mathrm{mol}$, respectively.

Turning our attention to the 2:1 structures, the most favorable in vacuum was structure $\mathbf{E}(-451.6 \mathrm{kcal} / \mathrm{mol})$, which was more energetically favorable than $\mathbf{D}$ by $4.8 \mathrm{kcal} / \mathrm{mol}$ and $\mathbf{F}$ by
$23.5 \mathrm{kcal} / \mathrm{mol}$. In methanol, the $2: 1$ structure with the most favorable interaction energy was $\mathbf{D}(-105.6 \mathrm{kcal} / \mathrm{mol})$ instead; $\mathbf{E}$ and $\mathbf{F}$ were 4.0 and $17.9 \mathrm{kcal} / \mathrm{mol}$ less favorable, respectively.

Among the structures with 2:1:1 stoichiometry, structure $\mathbf{H}$ $(-585.3 \mathrm{kcal} / \mathrm{mol})$ was more energetically favorable than $\mathbf{G}$ (by $2.2 \mathrm{kcal} / \mathrm{mol}$ ) and $\mathbf{I}$ (by $32.5 \mathrm{kcal} / \mathrm{mol}$ ) in vacuum. In methanol, the most favorable 2:1:1 structure was $\mathbf{G}$ $(-131.1 \mathrm{kcal} / \mathrm{mol})$, with $\mathbf{H}$ being less favorable by $8.7 \mathrm{kcal} /$ $\mathrm{mol}$ and $\mathbf{I}$ by $28.0 \mathrm{kcal} / \mathrm{mol}$.

Results of the energy calculations for the investigated schemes in vaccuum suggest that, in the presence of one molecule of colchicine, coordination via $\mathrm{O} 1$ and $\mathrm{O} 4$ is energetically most favorable, but in stoichiometries with two molecules of colchicine, coordination via $\mathrm{O} 5$ and $\mathrm{O} 6$ is favored. This may be explained by the size of the colchicine molecule, which may cause steric hindrance when coordination is attempted through atoms other than $\mathrm{O} 5$ and O6. Calculations show that, in methanol, the structure with the most favorable interaction energy always has one or both molecules of colchicine coordinated via $\mathrm{O} 1$ and $\mathrm{O} 4$. Our calculations show that colchicine can also coordinate via N1, but this is less favorable in both vacuum and methanol. The atomic coordinates of the obtained structures are included in Tables S2-S4 of the ESM.

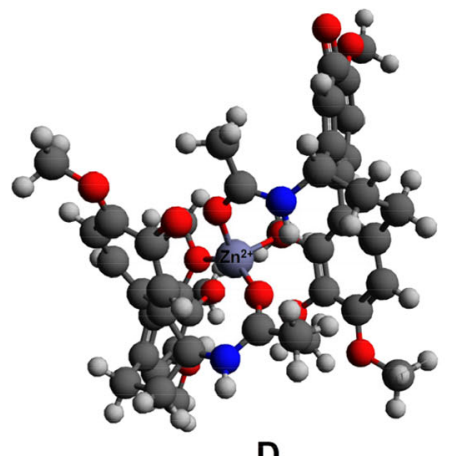

D

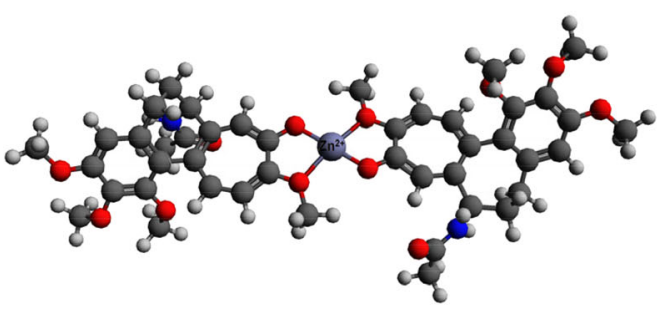

E

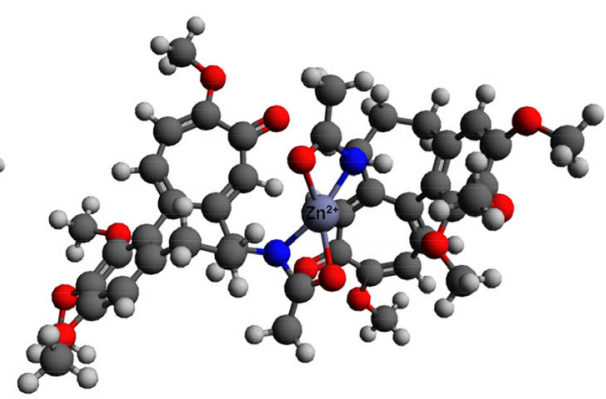

$\mathbf{F}$

Fig. 5 Optimized structures D-F with 2:1 stoichiometry 


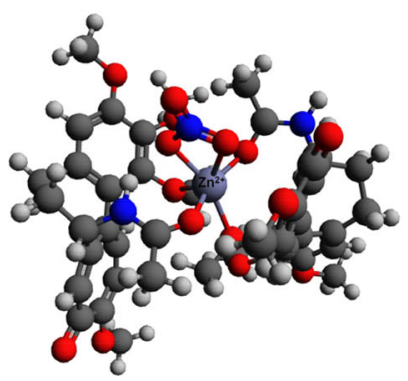

G

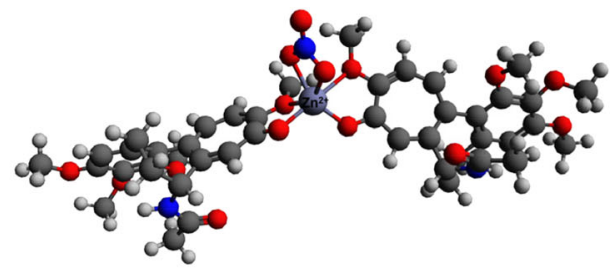

H

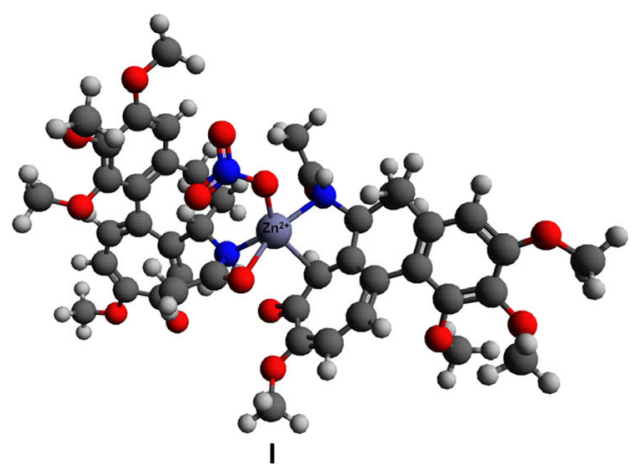

Fig. 6 Optimized structures $\mathbf{G}-\mathbf{I}$ with 2:1:1 stoichiometry

Selected interatomic distances, Mulliken point charges, and Wiberg bond indices are shown in Table 3. Table S5 in the ESM includes an extended version of Table 3 that presents rho and its Laplacian for bond critical points between the zinc(II) cation and the coordinating atoms.

In all of the structures $\mathbf{A}-\mathbf{I}$, the $\mathrm{Zn}^{2+} \ldots \mathrm{O} 6$ distance is the shortest: $1.856 \AA$ for $\mathbf{B}$ (1:1:1 stoichiometry); $1.850 \AA$ for $\mathbf{E}$ (2:1 stoichiometry); $1.925 \AA$ for $\mathbf{H}$ (2:1:1 stoichiometry). This suggests that the interaction between the central $\mathrm{Zn}$ (II) cation and the colchicine ligand is the strongest interaction in the complexes. Calculated Wiberg bond indices also confirmed that $\mathrm{Zn}^{2+} \ldots \mathrm{O} 6$ is the strongest interaction in each complex. The bond index for this bond was highest in each investigated structure.

The Mulliken partial charge on the zinc cation varied with the structure for each stoichiometry. Among the 1:1:1 structures, it ranged from $+0.761 e$ for $\mathbf{A}$ to $+0.836 e$ for $\mathbf{C}$. For a stoichiometry of 2:1, it ranged from $+0.514 e$ for $\mathbf{F}$ to $+0.728 e$ for $\mathbf{E}$. Among the 2:1:1 structures, it ranged from $+0.471 e$ for I to $+0.707 e$ for $\mathbf{H}$.

The calculated Mulliken point charges for the coordinating $\mathrm{O}$ and $\mathrm{N}$ atoms also varied with the structure for each complex stoichiometry. For the 1:1:1 structures, they ranged from
$-0.542 e$ for $\mathrm{O} 1$ in $\mathbf{C}$ to $-0.400 e$ for $\mathrm{O} 4$ in $\mathbf{A}$. For structures with a stoichiometry of 2:1, they ranged from $-0.711 e$ for $\mathrm{N} 1 \mathrm{~b}$ in $\mathbf{F}$ to $-0.236 e$ for $\mathrm{O} 4 \mathrm{~b}$ in $\mathbf{F}$. Among the 2:1:1 structures, they ranged from $-0.677 e$ for $\mathrm{N} 1 \mathrm{~b}$ in $\mathbf{I}$ to $-0.263 e$ for $\mathrm{O} 4 \mathrm{~b}$ in $\mathbf{I}$. As we can see, for both 2:1 and 2:1:1 structures, the calculated Mulliken charges when the colchicine coordinates via an nitrogen atom are most negative for the N1b atom and least negative for the $\mathrm{O} 4 \mathrm{~b}$ atom.

\section{NMR measurements}

NMR spectra for the colchicine complexes were measured and calculated in $\mathrm{CD}_{3} \mathrm{CN}$. Selected ${ }^{1} \mathrm{H}$ and ${ }^{13} \mathrm{C}$ NMR data for colchicine and its complexes with zinc nitrate are given in Tables 4 and 5, respectively (for the full data, see Tables S6-S13 in the ESM). The calculated ${ }^{1} \mathrm{H}$ NMR and ${ }^{13} \mathrm{C}$ NMR chemical shifts differed from those obtained experimentally. The main reason for those differences is the fact that we do not know which particular complex was examined experimentally. The smallest squared differences between the experimental and calculated chemical shifts were recorded for structure B (1:1:1) in the ${ }^{1} \mathrm{H}$ NMR spectrum (49.36) and
Table 2 Calculated interaction energies for the structures A-I of complexes of colchicine with zinc(II) nitrate in vacuum and methanol, as generated through the studied interaction schemes

\begin{tabular}{llll}
\hline $\begin{array}{l}\text { Structure label and } \\
\text { stoichiometry }\end{array}$ & \multicolumn{2}{l}{ Vacuum } & Methanol \\
\cline { 2 - 3 } & $\begin{array}{l}\text { Uncorrected interaction } \\
\text { energy }(\mathrm{kcal} / \mathrm{mol})\end{array}$ & $\begin{array}{l}\text { Corrected interaction } \\
\text { energy }(\mathrm{kcal} / \mathrm{mol})\end{array}$ & $\begin{array}{l}\text { Interaction energy } \\
(\mathrm{kcal} / \mathrm{mol})\end{array}$ \\
\hline $\mathbf{A}(1: 1: 1)$ & -980.3 & -970.2 & -102.6 \\
B $(1: 1: 1)$ & -965.7 & -957.8 & -93.0 \\
C $(1: 1: 1)$ & -939.5 & -931.5 & -79.6 \\
D $(2: 1)$ & -463.0 & -446.8 & -105.6 \\
E $(2: 1)$ & -459.9 & -451.6 & -101.6 \\
F $(2: 1)$ & -441.6 & -428.1 & -87.7 \\
G $(2: 1: 1)$ & -607.4 & -583.1 & -131.1 \\
H $(2: 1: 1)$ & -601.4 & -585.3 & -122.4 \\
I $(2: 1: 1)$ & -574.0 & -552.8 & -103.1 \\
\hline
\end{tabular}


Table 3 Selected geometric parameters, calculated Mulliken partial charges, and Wiberg bond indices for the structures A-I of complexes of colchicine with zinc(II) nitrate in vacuum and methanol, as generated through the studied interaction schemes

\begin{tabular}{|c|c|c|c|c|c|}
\hline $\begin{array}{l}\text { Structure label } \\
\text { and stoichiometry }\end{array}$ & $\begin{array}{l}\text { Mulliken partial charge } \\
\text { (in } e \text { ) on the zinc } \\
\text { (II) cation }\end{array}$ & $\begin{array}{l}\text { Coordinating atom } \\
(\mathrm{CA})\end{array}$ & $\begin{array}{l}\text { Mulliken partial } \\
\text { charge (in } e \text { ) on } \\
\text { the CA }\end{array}$ & $\begin{array}{l}\text { Distance between } \\
\text { the } \mathrm{CA} \text { and the } \\
\text { cation }(\AA)\end{array}$ & $\begin{array}{l}\text { Wiberg bond } \\
\text { index for } \mathrm{Zn}^{2+}-\mathrm{CA}\end{array}$ \\
\hline \multirow[t]{5}{*}{$\mathbf{A}(1: 1: 1)$} & \multirow[t]{5}{*}{0.761} & O1 & -0.478 & 2.067 & 0.162 \\
\hline & & $\mathrm{O} 2$ & -0.458 & 2.190 & 0.143 \\
\hline & & $\mathrm{O} 4$ & -0.400 & 1.939 & 0.278 \\
\hline & & $\mathrm{O} 1\left(\mathrm{NO}_{3}\right)$ & -0.263 & 2.015 & 0.291 \\
\hline & & $\mathrm{O} 2\left(\mathrm{NO}_{3}\right)$ & -0.236 & 2.096 & 0.244 \\
\hline \multirow[t]{4}{*}{ B $(1: 1: 1)$} & \multirow[t]{4}{*}{0.788} & O5 & -0.483 & 2.100 & 0.163 \\
\hline & & O6 & -0.450 & 1.856 & 0.398 \\
\hline & & $\mathrm{O} 1\left(\mathrm{NO}_{3}\right)$ & -0.260 & 2.023 & 0.299 \\
\hline & & $\mathrm{O} 2\left(\mathrm{NO}_{3}\right)$ & -0.263 & 2.015 & 0.306 \\
\hline \multirow{4}{*}{ C (1:1:1) } & \multirow[t]{4}{*}{0.836} & $\mathrm{O} 1$ & -0.542 & 1.964 & 0.238 \\
\hline & & $\mathrm{O} 2$ & -0.524 & 1.952 & 0.247 \\
\hline & & $\mathrm{O} 1\left(\mathrm{NO}_{3}\right)$ & -0.247 & 1.987 & 0.336 \\
\hline & & $\mathrm{O} 2\left(\mathrm{NO}_{3}\right)$ & -0.265 & 2.022 & 0.299 \\
\hline \multirow[t]{4}{*}{$\mathbf{D}(2: 1)$} & \multirow[t]{4}{*}{0.653} & O1a & -0.500 & 2.045 & 0.120 \\
\hline & & $\mathrm{O} 4 \mathrm{a}$ & -0.425 & 1.932 & 0.191 \\
\hline & & $\mathrm{O} 1 \mathrm{~b}$ & -0.528 & 1.983 & 0.128 \\
\hline & & $\mathrm{O} 4 \mathrm{~b}$ & -0.407 & 1.976 & 0.182 \\
\hline \multirow[t]{4}{*}{$\mathbf{E}(2: 1)$} & \multirow[t]{4}{*}{0.728} & O5a & -0.480 & 2.142 & 0.155 \\
\hline & & O6a & -0.475 & 1.850 & 0.398 \\
\hline & & $\mathrm{O} 5 \mathrm{~b}$ & -0.485 & 2.113 & 0.158 \\
\hline & & O6b & -0.475 & 1.854 & 0.400 \\
\hline \multirow[t]{4}{*}{$\mathbf{F}(2: 1)$} & \multirow[t]{4}{*}{0.514} & N1a & -0.582 & 2.029 & 0.247 \\
\hline & & $\mathrm{O} 4 \mathrm{a}$ & -0.255 & 2.215 & 0.175 \\
\hline & & $\mathrm{N} 1 \mathrm{~b}$ & -0.711 & 2.072 & 0.232 \\
\hline & & $\mathrm{O} 4 \mathrm{~b}$ & -0.236 & 2.153 & 0.197 \\
\hline \multirow[t]{6}{*}{$\mathbf{G}(2: 1: 1)$} & \multirow[t]{6}{*}{0.694} & O1a & -0.486 & 2.145 & 0.124 \\
\hline & & $\mathrm{O} 4 \mathrm{a}$ & -0.362 & 2.002 & 0.202 \\
\hline & & $\mathrm{O} 1 \mathrm{~b}$ & -0.473 & 2.273 & 0.115 \\
\hline & & $\mathrm{O} 4 \mathrm{~b}$ & -0.415 & 1.968 & 0.199 \\
\hline & & $\mathrm{O} 1\left(\mathrm{NO}_{3}\right)$ & -0.329 & 2.150 & 0.185 \\
\hline & & $\mathrm{O} 2\left(\mathrm{NO}_{3}\right)$ & -0.234 & 2.367 & 0.154 \\
\hline \multirow[t]{6}{*}{$\mathbf{H}(2: 1: 1)$} & \multirow[t]{6}{*}{0.707} & O5a & -0.434 & 2.213 & 0.124 \\
\hline & & O6a & -0.413 & 1.959 & 0.280 \\
\hline & & $\mathrm{O} 5 \mathrm{~b}$ & -0.409 & 2.466 & 0.082 \\
\hline & & $\mathrm{O} 6 \mathrm{~b}$ & -0.441 & 1.925 & 0.304 \\
\hline & & $\mathrm{O} 1\left(\mathrm{NO}_{3}\right)$ & -0.288 & 2.152 & 0.212 \\
\hline & & $\mathrm{O} 2\left(\mathrm{NO}_{3}\right)$ & -0.254 & 2.104 & 0.241 \\
\hline \multirow[t]{4}{*}{ I $(2: 1: 1)$} & \multirow[t]{4}{*}{0.471} & N1a & -0.574 & 2.192 & 0.141 \\
\hline & & N1b & -0.677 & 2.059 & 0.208 \\
\hline & & $\mathrm{O} 4 \mathrm{~b}$ & -0.263 & 2.274 & 0.161 \\
\hline & & $\mathrm{O} 1\left(\mathrm{NO}_{3}\right)$ & -0.371 & 1.957 & 0.283 \\
\hline
\end{tabular}

for the uncoordinated colchicine in the ${ }^{13} \mathrm{C}$ NMR spectrum (52.50)

In the ${ }^{1} \mathrm{H}$ NMR spectra, a doublet from the amine group $(\mathrm{NH})$ moves from $7.40 \mathrm{ppm}$ for uncoordinated colchinine to $7.55 \mathrm{ppm}$ for its complex with zinc(II) nitrate. This change can also be observed in the calculated data (e.g., from 5.37 for $\mathbf{1}$ to $6.19 \mathrm{ppm}$ for $\mathbf{B})$. There is also a notable change in the chemical shift calculated for one of the protons on $\mathrm{C} 2$ after coordination, from 3.92 in $\mathbf{1}$ to $3.94 \mathrm{ppm}$ in $\mathbf{B}$. Further, some changes in the chemical shifts of the protons on $\mathrm{C} 10$ upon complexation can be observed in both the measured and calculated spectra. Two protons on $\mathrm{C} 11$ and $\mathrm{C} 12$ that appear as neighboring doublets in the experimental spectrum of colchicine shift markedly after complexation; this phenomenon can also be seen when comparing the calculated spectra for $\mathbf{1}$ and $\mathbf{B}$. The proton on $\mathrm{C} 8$ in the ${ }^{1} \mathrm{H}$ NMR spectrum is observed as a singlet that shifts upon complexation. Again, this shift in the singlet from the proton on $\mathrm{C} 8$ can be seen by comparing the calculated spectra for $\mathbf{1}$ and $\mathbf{B}$. In the measured spectra, the singlet due to the proton on $\mathrm{C} 4$ does not shift upon complexation: it appears at $6.70 \mathrm{ppm}$ in the spectra for colchicine and its complex with zinc(II) nitrate. Similarly, signals from the protons on $\mathrm{C} 5$ and $\mathrm{C} 6$ remain almost unchanged after complexation in both the measured and calculated spectra. Finally, the proton signals from the four methoxy groups at $\mathrm{C} 1, \mathrm{C} 2$, $\mathrm{C} 3$, and $\mathrm{C} 10$ appear as four singlets in the region 3.59$4.06 \mathrm{ppm}$ in the ${ }^{1} \mathrm{H}$ NMR spectra measured both before and after complexation (see the ESM). 
Table 4 Selected experimental and calculated ${ }^{1} \mathrm{H}$ NMR chemical shift data for colchicine and its complexes

\begin{tabular}{|c|c|c|c|c|c|c|}
\hline \multirow[t]{3}{*}{ Hydrogen atom } & \multicolumn{6}{|c|}{ Chemical shift (ppm) } \\
\hline & \multicolumn{2}{|c|}{ Experimental } & \multicolumn{4}{|l|}{ Calculated } \\
\hline & Colchicine & $\begin{array}{l}\text { Colchicine- } \\
\mathrm{Zn}\left(\mathrm{NO}_{3}\right)_{2}\end{array}$ & Colchicine & $\mathbf{A}(1: 1: 1)$ & B $(1: 1: 1)$ & C $(1: 1: 1)$ \\
\hline $1 \mathrm{H}$ on $\mathrm{C} 8$ & 7.25 & 7.81 & 7.21 & 6.99 & 9.35 & 7.00 \\
\hline $1 \mathrm{H}$ on $\mathrm{C} 11$ & 6.93 & 7.5 & 7.67 & 6.79 & 7.57 & 6.52 \\
\hline $1 \mathrm{H}$ on $\mathrm{C} 12$ & 7.16 & 7.68 & 7.21 & 7.24 & 8.10 & 6.82 \\
\hline \multirow[t]{3}{*}{$3 \mathrm{H}$ on $\mathrm{CH}_{3} \mathrm{O}-2$} & 3.86 & 3.88 & 2.74 & 3.97 & 2.95 & 2.79 \\
\hline & & & 3.92 & 5.17 & 3.94 & 4.21 \\
\hline & & & 3.62 & 3.94 & 3.39 & 5.49 \\
\hline \multirow[t]{3}{*}{$3 \mathrm{H}$ on $\mathrm{OCH}_{3}-10$} & 3.9 & 4.06 & 3.28 & 4.08 & 4.21 & 4.06 \\
\hline & & & 3.87 & 3.85 & 4.18 & 3.74 \\
\hline & & & 2.00 & 1.77 & 2.07 & 1.76 \\
\hline $1 \mathrm{H}$ on $\mathrm{NH}$ & 7.4 & 7.55 & 5.37 & 5.10 & 6.19 & 5.50 \\
\hline$\sum(\text { calc }-\exp )^{2}$ & & & 58.14 & 52.03 & 49.36 & 80.90 \\
\hline
\end{tabular}

Switching our attention to the ${ }^{13} \mathrm{C}$ NMR spectra, both the experimental and calculated chemical shifts of carbon atoms on ring $\mathrm{A}(\mathrm{C} 1 \mathrm{a}-\mathrm{C} 4 \mathrm{a}$, see Fig. 1) show some changes after complexation, especially when the spectrum of $\mathbf{1}$ is compared to that for complex structure A (see Table 5). Some changes are also visible in the experimental chemical shifts for carbon atoms on ring B after complexation: the signal for C5 moves from 30.27 to $29.71 \mathrm{ppm}$; the signals for C6 and C7 move from 36.84 to $37.15 \mathrm{ppm}$ and from 52.95 to $54.22 \mathrm{ppm}$, respectively; and the signal for C7a moves from 152.01 to $155.32 \mathrm{ppm}$. Similar shifts in the signals from these atoms upon complexation are also seen in the calculated spectra: the signal for $\mathrm{C} 5$ changes from $30.27 \mathrm{ppm}$ (for 1) to $29.47 \mathrm{ppm}$ (for structure A); the signal for $\mathrm{C} 6$ changes from 34.27 (1) to $38.19 \mathrm{ppm}(\mathbf{A})$; and the signals for $\mathrm{C} 7$ and $\mathrm{C} 7$ a shift from 58.95 (1) to $65.98 \mathrm{ppm}(\mathbf{A})$ and from $147.81 \mathrm{ppm}(\mathbf{1})$ to $161.69 \mathrm{ppm}$ (B), respectively. After complexation, the signal from the $\mathrm{C} 4$ carbonyl carbon shifts from 179.63 to $178.48 \mathrm{ppm}$ when comparing the measured spectra and
Table 5 Selected experimental and calculated ${ }^{13} \mathrm{C}$ NMR chemical shift data for colchicine and its complexes

\begin{tabular}{|c|c|c|c|c|c|c|}
\hline \multirow[t]{3}{*}{ Carbon atom } & \multicolumn{6}{|c|}{ Chemical shift (ppm) } \\
\hline & \multicolumn{2}{|c|}{ Experimental } & \multicolumn{4}{|l|}{ Calculated } \\
\hline & Colchicine & Colchicine- $\mathrm{Zn}\left(\mathrm{NO}_{3}\right)_{2}$ & Colchicine & $\mathbf{A}(1: 1: 1)$ & B $(1: 1: 1)$ & $\mathbf{C}(1: 1: 1)$ \\
\hline $\mathrm{C} 1 \mathrm{a}$ & 126.57 & 125.29 & 123.46 & 128.09 & 121.80 & 119.28 \\
\hline $\mathrm{C} 3$ & 154.41 & 157.69 & 154.70 & 155.69 & 156.93 & 150.12 \\
\hline $\mathrm{C} 4 \mathrm{a}$ & 136.84 & 141.92 & 142.88 & 142.10 & 142.51 & 147.60 \\
\hline $\mathrm{C} 5$ & 30.27 & 29.71 & 30.27 & 29.47 & 30.85 & 30.08 \\
\hline C6 & 36.84 & 37.15 & 34.27 & 38.19 & 34.67 & 33.03 \\
\hline $\mathrm{C} 7$ & 52.95 & 54.22 & 58.95 & 65.98 & 55.40 & 57.38 \\
\hline $\mathrm{C} 7 \mathrm{a}$ & 152.01 & 155.32 & 147.81 & 142.22 & 161.69 & 146.12 \\
\hline C9 & 179.63 & 178.48 & 178.81 & 178.10 & 168.47 & 183.44 \\
\hline $\mathrm{C} 10$ & 164.88 & 163.14 & 163.83 & 165.01 & 157.02 & 163.10 \\
\hline $\mathrm{C} 11$ & 112.98 & 118.9 & 118.65 & 110.50 & 118.67 & 108.70 \\
\hline $\mathrm{C} 12$ & 136.66 & 140.13 & 141.82 & 134.16 & 148.05 & 138.43 \\
\hline $\mathrm{OCH}_{3}(1)$ & 61.61 & 61.95 & 62.63 & 69.02 & 62.70 & 73.42 \\
\hline $\mathrm{OCH}_{3}(10)$ & 56.76 & 58.33 & 61.16 & 59.38 & 61.94 & 58.93 \\
\hline $\mathrm{C}=\mathrm{O}\left(\mathrm{CH}_{3}\right)$ & 170.04 & 172.16 & 172.36 & 179.38 & 175.16 & 173.14 \\
\hline$\sum(\text { calc }-\exp )^{2}$ & & & 52.50 & 75.08 & 61.46 & 79.91 \\
\hline
\end{tabular}


Table 6 Experimental and calculated FT IR wavenumbers (v) for carbonyl groups of uncomplexed and complexed colchicine (measured in $\mathrm{KBr}$, nujol, or $\mathrm{CD}_{3} \mathrm{CN}$ and calculated in vacuum, nonpolar solvent, or $\mathrm{CD}_{3} \mathrm{CN}$ )

\begin{tabular}{|c|c|c|c|c|}
\hline & Measured/calculated in: & Structure or complex & $v(\mathrm{C} 13=\mathrm{O} 4)$ & $v(\mathrm{C} 9=\mathrm{O} 6)$ \\
\hline \multirow[t]{6}{*}{ Experimental data } & \multirow[t]{2}{*}{$\mathrm{KBr}$ pellet } & 1 & 1680 & 1615 \\
\hline & & Colchicine- $\mathrm{Zn}\left(\mathrm{NO}_{3}\right)_{2}$ & 1652 & 1601 \\
\hline & \multirow[t]{2}{*}{ Nujol } & 1 & 1656 & 1614 \\
\hline & & Colchicine- $\mathrm{Zn}\left(\mathrm{NO}_{3}\right)_{2}$ & 1652 & 1600 \\
\hline & \multirow[t]{2}{*}{$\mathrm{CD}_{3} \mathrm{CN}$} & 1 & 1681 & 1619 \\
\hline & & Colchicine- $\mathrm{Zn}\left(\mathrm{NO}_{3}\right)_{2}$ & 1669 & 1604 \\
\hline \multirow[t]{12}{*}{ Calculated data } & \multirow[t]{4}{*}{ Vacuum } & 1 & 1698 & 1583 \\
\hline & & $\mathbf{A}(1: 1: 1)$ & 1649 & 1641 \\
\hline & & B $(1: 1: 1)$ & 1692 & 1618 \\
\hline & & C $(1: 1: 1)$ & 1699 & 1682 \\
\hline & \multirow[t]{4}{*}{ Nonpolar solvent ${ }^{\mathrm{a}}$} & $1(1: 1: 1)$ & 1697 & 1581 \\
\hline & & $\mathbf{A}(1: 1: 1)$ & 1646 & 1657 \\
\hline & & B $(1: 1: 1)$ & 1697 & 1618 \\
\hline & & $\mathbf{C}(1: 1: 1)$ & 1700 & 1684 \\
\hline & \multirow[t]{4}{*}{$\mathrm{CD}_{3} \mathrm{CN}$} & $1(1: 1: 1)$ & 1695 & 1578 \\
\hline & & $\mathbf{A}(1: 1: 1)$ & 1636 & 1644 \\
\hline & & B $(1: 1: 1)$ & 1696 & 1619 \\
\hline & & $\mathbf{C}(1: 1: 1)$ & 1699 & 1685 \\
\hline
\end{tabular}

a Parameters: dielectric constant, 2.06; solvent radius, $2.0 \AA$; refractive index, 1.4338 ; molar volume, $272 \mathrm{~cm}^{3}$ / mol

from 178.81 to $178.10 \mathrm{ppm}$ when comparing the calculated spectra for $\mathbf{1}$ and A. Complexation also causes changes in the chemical shifts of the carbon atoms neighboring the oxygen atoms of the methoxy and carbonyl groups: the experimental and calculated signals from $\mathrm{C} 11$ and $\mathrm{C} 12$ on ring $\mathrm{C}$ show marked shifts upon complexation.

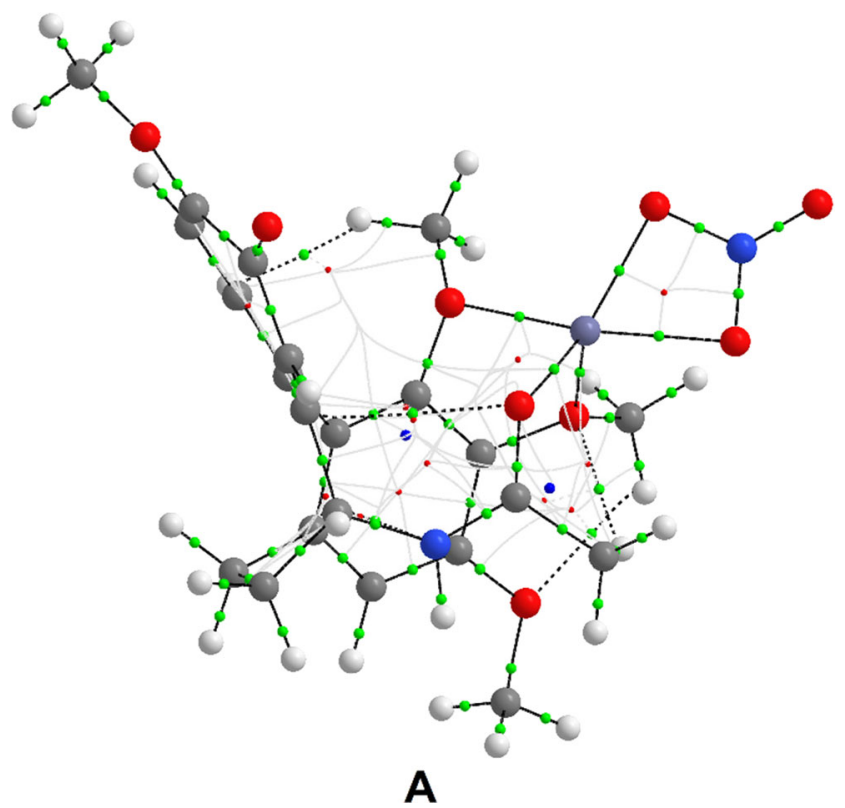

Fig. 7 Bond paths (black) and bond critical points (green) of the most energetically favorable [colchicine $+\mathrm{Zn}(\mathrm{II})+\mathrm{NO}_{3}$ ] complex structure $\mathbf{A}$ (i.e., 1:1:1 stoichiometry)
It is therefore clear that the experimental and calculated NMR spectral data present similar trends in chemical shift movements upon complexation.

\section{FT IR measurements}

FT IR spectra of the uncoordinated and complexed colchicine were measured in the solid state (i.e., $\mathrm{KBr}$ pellets), in nujol, and in $\mathrm{CD}_{3} \mathrm{CN}$. The corresponding spectra were also calculated in vacuum, a nonpolar solvent (with a dielectric constant of 2.06, a solvent radius of $2.0 \AA$, a refractive index of 1.4338 , and a molar volume of $272 \mathrm{~cm}^{3} / \mathrm{mol}$ ), and $\mathrm{CD}_{3} \mathrm{CN}$. Data for the carbonyl groups are given in Table 6. In the experimental FT IR spectra (in nujol), the band from stretching vibrations of the carbonyl group $\mathrm{C} 13=\mathrm{O} 4$ does not shift much upon complexation, while the band from stretching vibrations of the carbonyl group $\mathrm{C} 9=\mathrm{O} 6$ on tropolone ring $\mathrm{C}$ shifts $14 \mathrm{~cm}^{-1}$ lower upon complexation. Similar behavior was observed for the latter band in the experimental FT IR spectra obtained with $\mathrm{KBr}$ pellets and in $\mathrm{CD}_{3} \mathrm{CN}$ solution; upon complexation, the band shifts from 1680 to $1652 \mathrm{~cm}^{-1}$ when using $\mathrm{KBr}$ pellets and from 1681 to $1669 \mathrm{~cm}^{-1}$ in $\mathrm{CD}_{3} \mathrm{CN}$ solution. Calculated FT IR spectra in the nonpolar solvent show similar results, especially when the spectrum for $\mathbf{1}$ is compared to those for complex structures $\mathbf{B}$ and $\mathbf{C}$ : the band from carbonyl group C13=O4 does not shift much upon complexation from $\mathbf{1}$ to $\mathbf{B}$ or $\mathbf{C}$, while the band for carbonyl group $\mathrm{C} 9=\mathrm{O} 6$ shifts towards higher wavenumbers upon complexation from $\mathbf{1}$ to structure $\mathbf{A}$ (by $37 \mathrm{~cm}^{-1}$ ) or structure $\mathbf{C}$ (by $103 \mathrm{~cm}^{-1}$ ). All of the calculated 
Fig. 8 Bond paths (black) and bond critical points (green) of the most energetically favorable $[2 \times$ colchicine $+\mathrm{Zn}(\mathrm{II})]$ complex structure $\mathbf{E}$ (i.e., 2:1 stoichiometry)

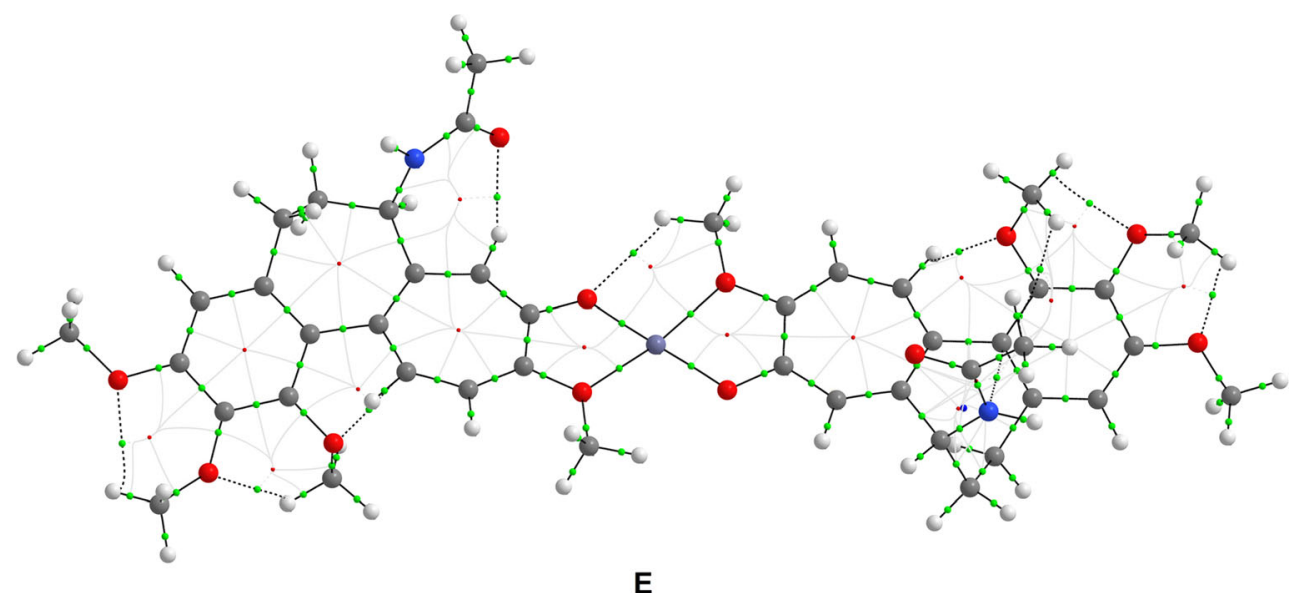

spectra (i.e., those obtained in vacuum, nonpolar solvent, and $\mathrm{CD}_{3} \mathrm{CN}$ ) showed similarities. Upon complexation to structure A, there are notable changes in the stretching bands for carbonyls $\mathrm{C} 13=\mathrm{O} 4$ and $\mathrm{C} 9=\mathrm{O} 6$, whereas complexation to structure $\mathbf{B}$ or $\mathbf{C}$ only significantly changes the band for carbonyl $\mathrm{C} 9=\mathrm{O} 6$ (shifting it towards higher wavenumbers). The full measured and calculated FT IR spectra are given in Figs. S2S19 of the ESM.

\section{Bond path and bond critical points}

We generated wfn files for all of the structures of colchicine complexed with $\mathrm{Zn}$ (II) and used them to find bond paths and bond critical points using AIMPAC. Figures 7-9 show the resulting complex structures with the lowest interaction energies (other structures are included in Figs. S20-S25 of the ESM). The figures demonstrate that all of the atoms in colchicine that were initially selected as coordinating atoms form bonds with the central zinc cation according to the quantum theory of atoms in molecules. The bond paths and bond critical points indicate that colchicine can coordinate to $\mathrm{Zn}$ (II). In one of the investigated complex structures containing a nitrate anion (structure I with a stoichiometry of 2:1:1), this anion coordinates to the central zinc cation via one oxygen atom rather than two. The bond paths and bond critical points for this complex (see Fig. S25 in the ESM) indicate that one of the oxygen atoms in the nitrate anion is involved in a hydrogen bond, which may explain why it does not coordinate to the zinc cation.

\section{Conformation of the seven-membered ring of colchicine}

Table 7 presents dihedral angles and calculated amplitudes of the puckering and phase angles for the seven-membered ring in the most energetically favorable structures of each colchicine complex (see Tables S14-S16 in the ESM for the coordinates of the atoms in the seven-membered ring).

The calculated parameters of the seven-membered rings in structures $\mathbf{A}(1: 1: 1)$ and $\mathbf{H}(2: 1: 1)$ suggest that those rings are in a twisted boat conformation (as defined by Cremer and Pople [36]), which is also the case for the seven-membered ring of one of the colchicine molecules in structure $\mathbf{E}$ (2:1). All of those rings have almost the same puckering amplitudes and phase angles. The calculated parameters for the seven-
Fig. 9 Bond paths (black) and bond critical points (green) of the most energetically favorable $\left[2 \times\right.$ colchicine $\left.+\mathrm{Zn}(\mathrm{II})+\mathrm{NO}_{3}\right]$ complex structure $\mathbf{H}$ (i.e., $2: 1: 1$ stoichiometry)

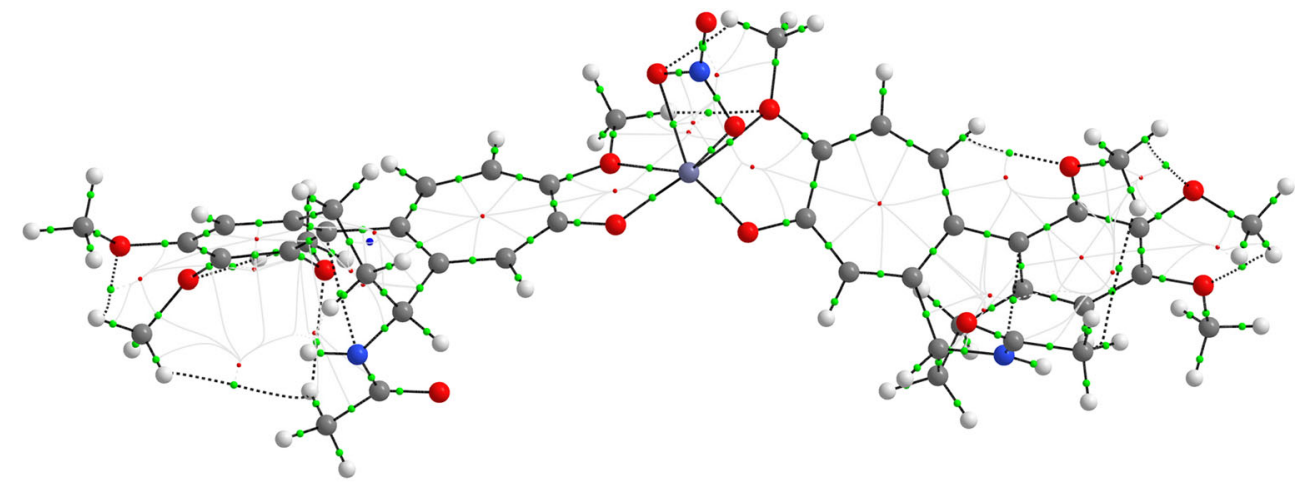

H 
Table 7 Dihedral angles and calculated puckering amplitudes and phase angles of the seven-membered ring in the most energetically favorable complexes of colchicine with a zinc(II) cation (and, in some cases, a nitrate anion)

\begin{tabular}{|c|c|c|c|c|c|c|c|c|}
\hline & & \multicolumn{5}{|c|}{ Colchicine complex structure and stoichiometry } & \multicolumn{2}{|c|}{ Crystal structure } \\
\hline & & $\mathbf{A}(1: 1: 1)$ & $\mathbf{E}(2: 1)$ & & $\mathbf{H}(2: 1$ & & DAECOL $^{\mathrm{b}}$ & $\mathrm{ISCHOL}^{\mathrm{c}}$ \\
\hline \multirow[t]{7}{*}{ Dihedral angle $\left(^{\circ}\right)$} & $\mathrm{C} 12 \mathrm{a}-\mathrm{C} 1 \mathrm{a}-\mathrm{C} 4 \mathrm{a}-\mathrm{C} 5$ & 5.4 & 11.6 & -1.6 & -5.0 & -2.6 & -5.6 & -6.6 \\
\hline & $\mathrm{C} 1 \mathrm{a}-\mathrm{C} 4 \mathrm{a}-\mathrm{C} 5-\mathrm{C} 6$ & -72.0 & 60.9 & -72.6 & -71.1 & -71.8 & 75.6 & -68.2 \\
\hline & $\mathrm{C} 4 \mathrm{a}-\mathrm{C} 5-\mathrm{C} 6-\mathrm{C} 7$ & 31.3 & -91.9 & 46.1 & 47.0 & 44.9 & -58.9 & 43.5 \\
\hline & $\mathrm{C} 5-\mathrm{C} 6-\mathrm{C} 7-\mathrm{C} 7 \mathrm{a}$ & 52.2 & 48.9 & 40.4 & 40.1 & 41.9 & -1.8 & 44.3 \\
\hline & $\mathrm{C} 6-\mathrm{C} 7-\mathrm{C} 7 \mathrm{a}-\mathrm{C} 12 \mathrm{a}$ & -58.1 & -6.7 & -76.1 & -76.7 & -74.9 & 8.9 & -78.1 \\
\hline & $\mathrm{C} 7-\mathrm{C} 7 \mathrm{a}-\mathrm{C} 12 \mathrm{a}-\mathrm{C} 1 \mathrm{a}$ & -21.2 & 19.0 & 7.2 & 7.4 & 4.4 & 45.9 & 5.6 \\
\hline & $\mathrm{C} 7 \mathrm{a}-\mathrm{C} 12 \mathrm{a}-\mathrm{C} 1 \mathrm{a}-\mathrm{C} 4 \mathrm{a}$ & 62.3 & -47.8 & 48.1 & 51.0 & 51.0 & -61.2 & 52.6 \\
\hline \multirow[t]{2}{*}{ Puckering amplitude $(\AA)$} & $\rho 2$ & 1.115 & 0.686 & 1.081 & 1.105 & 1.093 & 0.826 & 1.091 \\
\hline & $\rho 3$ & 0.065 & 0.408 & 0.142 & 0.132 & 0.130 & 0.289 & 0.127 \\
\hline \multirow[t]{2}{*}{ Phase angle $\left(^{\circ}\right)$} & $\varphi 2$ & 1.1 & 223.5 & 16.2 & 17.3 & 15.2 & 183.3 & 16.7 \\
\hline & $\varphi 3$ & 63.7 & 339.5 & 61.9 & 60.8 & 60.2 & 348.9 & 53.0 \\
\hline Conformation $^{\mathrm{a}}$ & & TB5 & $\mathrm{TC} 1$ & TB5 & TB5 & TB5 & $\mathrm{TC} 1$ & TB5 \\
\hline
\end{tabular}

membered ring of the other colchicine molecule in structure $\mathbf{E}$ suggest that that ring is in a twisted chair conformation instead. Based on the calculated puckering values for complexes and the crystal structures, we can infer that complexation does not affect the conformation of the seven-membered ring of colchicine.

\section{Conclusions}

In this work, quantum-mechanical computations together with calculated chemical shifts and comparisons with experimental data were used to determine the most probable complexes of colchicine with zinc(II) nitrate in solution. Calculations show that, in methanol, the most probable complex structure with a stoichiometry of 2:1:1 is $\mathbf{G}$, while $\mathbf{D}$ and $\mathbf{A}$ have the lowest interaction energies of the 2:1 and 1:1:1 complex structures, respectively. In methanol, the most favorable interaction energy is always obtained when one or both molecules of colchicine coordinate to the zinc(II) cation via oxygen atoms $\mathrm{O} 1$ and O4. Quantum-mechanical calculations show that, in vacuum, the most probable structure for each complex stoichiometry is A $(1: 1: 1), \mathbf{E}(2: 1)$, and $\mathbf{H}(2: 1: 1)$. It was also found that the nitrogen atom of colchicine can act as a donor, but such coordination is significantly less energetically favored than coordination through oxygen atoms.

Acknowledgments This research was supported in part by PL-Grid Infrastructure; the authors are grateful for being permitted to use all of the computer programs they required. The authors also wish to thank the anonymous reviewers for their feedback, which helped to significantly improve the manuscript.

Publisher's Note Springer Nature remains neutral with regard to jurisdictional claims in published maps and institutional affiliations.

Author contributions All of the authors contributed to the manuscript and approved the final version of it.

\section{Compliance with ethical standards}

Founding sources None.

Conflict of interest The authors declare no competing financial interest.

Open Access This article is distributed under the terms of the Creative Commons Attribution 4.0 International License (http:// creativecommons.org/licenses/by/4.0/), which permits unrestricted use, distribution, and reproduction in any medium, provided you give appropriate credit to the original author(s) and the source, provide a link to the Creative Commons license, and indicate if changes were made.

\section{References}

1. Cutler S, Cutler H (2000) Biologically active natural products: pharmaceuticals. CRC, New York

2. Bhat S, Nagasampagi B, Sivakumar M (2005) Chemistry of natural products. Narosa, New Delhi

3. Capraro H, Brossi A (1984) The alkaloids. Academic, New York

4. Budavari S (1989) The Merck index: an encyclopedia of chemicals, drugs, and biologicals. Harcourt Brace Jovanovich, London 
5. Roubille F, Kritikou E, Busseuil D et al (2013) Colchicine: an old wine in a new bottle? Antiinflamm Antiallergy Agents Med Chem 12:14-23

6. Pelegrín P (2011) Many ways to dilate the P2X7 receptor pore. Br J Pharmacol 163:908-911. doi:10.1111/j.1476-5381.2011.01325.x

7. Patel AJ, Honoré E, Lesage F et al (1999) Inhalational anesthetics activate two-pore-domain background $\mathrm{K}^{+}$channels. Nat Neurosci 2:422-426. doi: $10.1038 / 8084$

8. Morrison JD (1951) Preliminary examination of the crystal structures of colchiceine and its copper salt. Acta Crystallogr 4:69-71

9. Mackay MF, Gable RW, Morrison JD, Satzke LO (1999) Structure of hydrated copper(II) colchiceine. Aust J Chem 52:333-338

10. Joanna Kurek WB (2007) ESI MS, spectroscopic and PM5 semiempirical studies of colchicine complexes with lithium, sodium and potassium salts. J Mol Struct 846:13-22. doi:10.1016/j.molstruc. 2007.01.004

11. Ede Bodoki DB (2015) Ab initio study of the Na-colchicine positively charged complex. Farmacia 63:539-542

12. Parkin $\mathrm{G}$ (2007) Applications of tripodal $\left[S_{3}\right]$ and $\left[\mathrm{Se}_{3}\right] \mathrm{L}_{2} \mathrm{X}$ donor ligands to zinc, cadmium and mercury chemistry: organometallic and bioinorganic perspectives. New J Chem 31:1996-2014. doi:10. 1039/B712012E

13. Malczewska-Jaskóła K, Jankowski W, Warżajtis B et al (2015) Chalcogenated $(S)-(-)$-nicotine derivatives as chiral linkers for 1D coordination polymers. Polyhedron 100:404-411. doi:10.1016/j. poly.2015.08.027

14. Stanojkovic TP, Kovala-Demertzi D, Primikyri A et al (2010) Zinc(II) complexes of 2-acetyl pyridine 1-(4-fluorophenyl)piperazinyl thiosemicarbazone: synthesis, spectroscopic study and crystal structures - potential anticancer drugs. J Inorg Biochem 104:467-476. doi:10.1016/j.jinorgbio.2009.12.021

15. Andreini C, Banci L, Bertini I, Rosato A (2006) Counting the zincproteins encoded in the human genome. J Proteome Res 5:196-201. doi:10.1021/pr050361j

16. Broadley MR, White PJ, Hammond JP et al (2007) Zinc in plants. New Phytol 173:677-702. doi:10.1111/j.1469-8137.2007.01996.x

17. Walkup GK, Burdette SC, Lippard SJ, Tsien RY (2000) A new cellpermeable fluorescent probe for $\mathrm{Zn}^{2+}$. J Am Chem Soc 122:5644 5645. doi:10.1021/ja000868p

18. Hellmich HL, Frederickson CJ, DeWitt DS et al (2004) Protective effects of zinc chelation in traumatic brain injury correlate with upregulation of neuroprotective genes in rat brain. Neurosci Lett 355:221-225. doi:10.1016/j.neulet.2003.10.074

19. Lessinger L, Margulis TN (1978) The crystal structure of colchicine. A new application of magic integers to multiple-solution direct methods. Acta Crystallogr B 34:578-584. doi:10.1107/ S0567740878003568

20. Zhao Y, Truhlar DG (2008) The M06 suite of density functionals for main group thermochemistry, thermochemical kinetics, noncovalent interactions, excited states, and transition elements: two new functionals and systematic testing of four M06-class functionals and 12 other functionals. Theor Chem Accounts 120:215241. doi:10.1007/s00214-007-0310-x

21. Dunning TH Jr, Hay PJ (1976) In: Schaefer HF (ed) Modern theoretical chemistry. Plenum, New York, pp 1-28

22. Bregier-Jarzębowska R, Malczewska-Jaskóła K, Jankowski W et al (2015) Experimental and quantum-chemical studies of anabasine complexes with copper(II) and zinc(II) ions. Polyhedron 85:841848. doi:10.1016/j.poly.2014.10.008

23. Mulliken RS (1955) Electronic population analysis on LCAO-MO molecular wave functions. I. J Chem Phys 23:1833-1840. doi:10. $1063 / 1.1740588$
24. Wiberg KB (1968) Application of the Pople-Santry-Segal CNDO method to the cyclopropylcarbinyl and cyclobutyl cation and to bicyclobutane. Tetrahedron 24:1083-1096. doi:10.1016/00404020(68)88057-3

25. Foster JP, Weinhold F (1980) Natural hybrid orbitals. J Am Chem Soc 102:7211-7218. doi:10.1021/ja00544a007

26. Alan E, Reed FW (1983) Natural bond orbital analysis of nearHartree-Fock water dimer. J Chem Phys 78:4066-4073. doi:10. 1063/1.445134

27. Boys SF, Bernardi F (1970) The calculation of small molecular interactions by the differences of separate total energies. Some procedures with reduced errors. Mol Phys 19:553-566. doi:10.1080/ 00268977000101561

28. Simon S, Duran M, Dannenberg JJ (1996) How does basis set superposition error change the potential surfaces for hydrogenbonded dimers? J Chem Phys 105:11024-11031. doi:10.1063/1. 472902

29. Jensen F (2008) Basis set convergence of nuclear magnetic shielding constants calculated by density functional methods. J Chem Theory Comput 4:719-727. doi:10.1021/ct800013z

30. Saielli G, Nicolaou KC, Ortiz A et al (2011) Addressing the stereochemistry of complex organic molecules by density functional theory-NMR: vannusal B in retrospective. J Am Chem Soc 133:60726077. doi:10.1021/ja201108a

31. Cheeseman JR, Trucks GW, Keith TA, Frisch MJ (1996) A comparison of models for calculating nuclear magnetic resonance shielding tensors. J Chem Phys 104:5497-5509. doi:10.1063/1. 471789

32. Tomasi J, Mennucci B, Cammi R (2005) Quantum mechanical continuum solvation models. Chem Rev 105:2999-3093. doi:10. 1021/cr9904009

33. Clark T, Chandrasekhar J, Spitznagel GW, Schleyer PVR (1983) Efficient diffuse function-augmented basis sets for anion calculations. III. The $3-21+\mathrm{G}$ basis set for first-row elements, Li-F. J Comput Chem 4:294-301. doi:10.1002/jcc.540040303

34. Richard F, Bader W (1995) Atoms in molecules: a quantum theory. Clarendon, Oxford

35. Frisch MJ, Trucks GW, Schlegel HB et al (2009) Gaussian 09, revision A.1. Gaussian, Inc., Wallingford

36. Cremer D, Pople JA (1975) General definition of ring puckering coordinates. J Am Chem Soc 97:1354-1358. doi:10.1021/ ja00839a011

37. Boessenkool IK, Boeyens JCA (1980) Identification of the conformational type of seven-membered rings. J Cryst Mol Struct 10:1118. doi:10.1007/BF01209549

38. Bocian DF, Pickett HM, Rounds TC, Strauss HL (1975) Conformations of cycloheptane. J Am Chem Soc 97:687-695. doi:10.1021/ja00837a001

39. Kurek J, Bartkowiak G, Jankowski W et al (2016) Human body fluid ions in colchicine complexes ESI MS, MADLI MS, spectroscopic, DFT studies and fungicidal activity of colchicine complexes with sodium, potassium, magnesium and calcium carbonates and sulphates. IOSR J Pharm 06:40-55. doi:10.9790/3013-068024055

40. Busetta $\mathrm{B}$, Leroy F, Hospital $\mathrm{M}$ et al (1979) $O, N$-Diacétate de l'énol de colchicine. Acta Crystallogr B 35:1525-1527. doi:10.1107/ S056774087900697X

41. Lessinger L, Margulis TN (1978) The crystal structure of isocolchicine, an inactive isomer of the mitotic spindle inhibitor colchicine. Acta Crystallogr B 34:1556-1561. doi:10.1107/ S056774087800607X 